\title{
Preparing a high-performance surgical team: lessons from 11,000 surgeries
}

1. Instituto do Câncer, Universidade de São Paulo, São Paulo, SP, Brasil.

\section{SUMMARY}

INTRODUCTION: In the future, surgery will be centralized in hospitals with the best value (excellent results with reduced cost). High-performance teams will be required; however, available data concerning the specific abilities necessary to build and manage them are poor. OBJECTIVES: Share the set of competencies and skills established to build and lead a high-performance general surgery team.

METHODS: In November 2012, a general surgery team started its activities at a tertiary hospital in Sao Paulo, Brasil. The model consisted of high volume performed by a small team. Experienced surgeons, motivated, and with technical and moral excellence were selected. A sense of unity was created and goals were shared. Complex cases were discussed daily and a prospective database to follow outcomes was established. The payment value was above the market.

RESULTS: In 6 years and 4 months, 11,006 surgical procedures were performed (8,597 electives and 2,409 in an urgent setting). Cholecystectomy was the most common procedure (4,101; being 3,676 electives), followed by inguinal hernioplasty ( $n: 1,827)$ and appendectomy (n: 925). A total of 449 elective oncologic procedures were performed. The surgical site infection rate in clean procedures was $0.12 \%, 80$ patients required re-do surgery (2.4\% in an urgent setting and $0.2 \%$ of the electives). There were 22 postoperative deaths ( $0.66 \%$ for urgent and $0.07 \%$ for electives), 5 of the 6 deaths in elective patients were in oncologic cases.

CONCLUSION: A competent surgical team, inserted in a model that favors performance and values the individual can deliver high volume with exceptional results.

KEYWORDS: Patient Care Team. General surgery. Health Management. Outcome Assessment, Health Care.

\section{INTRODUCTION}

Healthcare expenditure is a major issue worldwide. As life expectancy increases and new exams, treatments, and procedures appear, income destined for healthcare rises. Healthcare is a right, and there is the moral obligation to provide it; nevertheless, there are income restrictions and even more complex decisions, such as where to place a limited budget. In this context, attention should be given to value in healthcare. Let us consider the value of a determined treatment as the result achieved per monetary $\operatorname{cost}^{1-3}$.

Great value can be achieved by a high-performance team, who is able to perform high volume at high speed, delivering excellent results, ultimately resulting in low monetary cost. But, how to build and lead this team? In sports and business, literature is vast; however, available data about high-performance medical team are scarce ${ }^{4}$. 


\section{OBJECTIVES}

The main objective of this article is to present the building and management of a high-performance general surgery team, sharing the ideas and solutions implemented and the results achieved.

\section{METHODS}

In 2012, a tertiary hospital in Sao Paulo, Brasil (Hospital Santa Cecilia) required a high-volume general surgery team. The hospital belonged to a healthcare insurance company that requested volume under a low budget.

\section{Volume}

The insurer needed a general surgery group to perform monthly up to 140 surgical procedures and 1,200 clinical evaluations (Table 1). The team would be responsible for inpatients and available $24 / 7$ for evaluations of patients from other medical specialties, including the emergency department (ED) and intensive care unit (ICU). The ED received 4,500 to 6,000 visits monthly, and the ICU had 20 beds.

TABLE 1. HOSPITAL'S VOLUME REQUIREMENTS

\begin{tabular}{|c|c|c|}
\hline \multicolumn{3}{|l|}{ Surgical procedures } \\
\hline & Electives & 100 \\
\hline & Urgency/emergency & $30-40$ \\
\hline \multicolumn{3}{|l|}{ Evaluations } \\
\hline & Inpatients & 400 \\
\hline & Outpatients & 800 \\
\hline
\end{tabular}

\section{Team structure}

The team was structured on weekdays with one surgeon in the outpatient clinic (30 patients in $6 \mathrm{~h}$ period) and two surgeons and one scrub nurse in the hospital. On weekends, one surgeon was responsible for the inpatients and the second stayed on call at home.

The 2 surgeons in the hospital were responsible for the team`s inpatients, evaluations requested from other specialties, elective surgical procedures scheduled, and any eventual urgent surgical pathology. After the end of their activities, both remained available at home (one was responsible for all calls and in-hospital evaluations, and the other available for surgery when necessary). Surgeries started at 8 am, and two surgical rooms were available for the team daily.
The outpatient clinic opened in September 2012, and the hospital's activities were started in the following month.

Initially, 4 electives were programmed every day, this was raised to 5 as demand expanded. After June 2016, another team of 2 surgeons and 1 scrub nurse were assigned for oncologic procedures, with one day per week for surgery and one period for outpatients (20 patients in $4 \mathrm{~h}$ ).

Initially, the whole team consisted of four surgeons and one scrub nurse. After a few months, a couple of surgeons were incorporated and, in June 2018, five more surgeons and one scrub nurse were added.

\section{Team selection}

Once the structure was defined, surgeons were interviewed. The objective was to identify if they were fit for the intended model. The profile desired included technical competency, ability to work in group, commitment to the proposed goals, and plasticity to share the team mindset. The main questions during this process were: résumé and medical formation discussion, experience in general and laparoscopic surgery, previous jobs, ethics, ability to work under stress. They were also informed on the volume and results desired, and the monetary value.

Surgeons were required to be board certified in general surgery and proficient in laparoscopic access.

The scrub nurse underwent a similar interview and was also board certified.

\section{Patient management}

The team had access to a cell phone app where all inpatients were presented daily. Complex outpatient cases were also discussed. Decisions were shared and the leader moderated the debates and was ultimately responsible for hard decisions.

Protocols were created and implemented to ensure patient safety. Flowcharts contemplating the clinical thinking and exams recommended for the most common surgical pathologies observed in the ED were also developed. Pre-operative protocols were created for outpatients.

A multidisciplinary culture focused on the patient was established in the hospital, engaging anesthesiologists, nurses, and other teams in achieving high-performance.

The surgical ward required profound culture and equipment changes to support the volume desired without sacrificing safety. Standardization 
of the equipment used in the most common procedures was implemented, allowing easy and efficient stock management.

\section{Payment}

Patients were treated in facilities from their insurance company, making no direct payment to the surgical team. The monetary value was previously agreed on and was based on the number of hours the team worked. The value for staying on call at a distance was established as $1 / 3$ of the one in-hospital. The capital per hour worked was above the market.

\section{RESULTS}

In 76 months (November 2012 to February 2019), 11,006 surgical procedures were performed (Table 2). A total of 8,597 were elective and 2,409 were performed in a urgency/emergency setting. Women accounted for $52 \%$ ( $n: 5,762)$ of the patients. The most common elective procedures were cholecystectomy ( $n: 3,676)$ and inguinal hernia repair $(n: 1,827)$, while appendectomy was the most frequent urgent surgery ( $n$ : 925). The mean hospital stay was 2.1 days. The suspension index was $0.1 \%$, with upper respiratory tract infection as the most common cause. Surgical site infection in clean elective surgery was $0.12 \%$ and higher in incisional hernia repair (3.3\%).

Eighty patients required surgical redo, $2.4 \%$ in urgency patients and $0.2 \%$ in elective ones. In the period, 22 (0.19\%) deaths occurred: 0.66\% and 0.07\% for urgency and elective, respectively. Thirteen deaths were of oncologic patients, including 5 out of the 6 deaths that occurred in elective patients. Deaths not related to the surgical procedure (e.g., terminal or palliative patients who required a feeding tube and

TABLE 2. SURGICAL PROCEDURES PER YEAR.

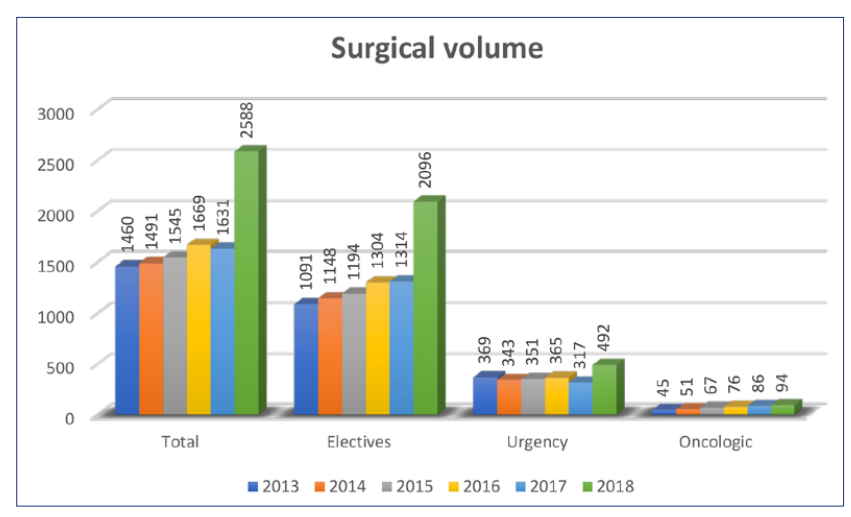

*2012 and 2019 not contemplated eventually died due to clinical complications unrelated to the surgical procedure) were not computed.

Surgery volume increased over the years; at the beginning, the number of elective cases was restricted, slowly rising over time. Urgent procedures also increased, except in 2017 (Table 2). A boost in volume occurred in 2018 after expanding the team.

Considering the most performed surgery, i.e, cholecystectomy $(n: 4,121)$, laparoscopic access was performed in 4,101 cases with conversion to open surgery in $0.2 \%$ of them. Five reoperations were necessary $(0.02 \%)$, three $(0.07 \%)$ were due to biliary leakage, and two $(0.04 \%)$ due to iatrogenic intestinal perforation. There was one death, an 84-year-old female admitted in the ED in septic shock due to acute cholecystitis (0.2\% mortality, considering the 445 urgent cholecystectomies performed).

In total, 449 oncologic procedures were performed, with a mortality rate of $1.1 \%$. Most procedures were performed laparoscopically (67\%). Among the major procedures performed, there were: low abdominal resection ( $n: 61)$, gastrectomy $(n: 52)$, distal pancreatectomy ( $n: 19)$, pancreaticoduodenectomy ( $n: 17)$, hepatectomy ( $n: 10)$, esophagectomy ( $n: 6)$. No reoperations or mortality were observed in pancreaticoduodenectomy or esophagectomy. Positive margins occurred in $10 \%$ of the pancreaticoduodenectomies.

Team member's suggestions and demands were always considered and incorporated whenever possible. Individual feedback was given monthly, and when a negative event or criticism occurred, immediate feed-back was given and a meeting arranged for the same week. Highly demanding patients or families (for medical or social condition) were followed-up closely by the team leader (daily if necessary). In 76 months, only 1 surgeon was replaced. Periodic social meetings were promoted and an official meeting occurred at the end of every year; the team's performance and results were presented, followed by a social gathering along with their respective families.

Rare procedures were performed during the 72 months period, some were presented and received honorary mentions at the Brazilian Digestive Week, others were published ${ }^{5-7}$.

\section{DISCUSSION}

Healthcare in Brasil is complex. Although there is a universal healthcare system (SUS) run by the government and sustained with taxes, private health 
insurances are common. This happens because SUS has few isles of excellence and long waiting lists for medical assistance and exams.

There are private insurances for all budgets and the quality of healthcare granted scales accordingly. More recently, few insurance companies started building their own healthcare system. Instead of reimbursing a third party, everything, from exams to surgeries, is done in their units. By doing so, their expenditure is limited and the profits potentialized. This allows them to provide budget health insurance to industries and companies with thousands of low-income employees.

However, the best interest of patients, healthcare providers, and the insurer may not always be the same.

In this context, one major insurer asked for a budget high-volume general surgery team. The main issue was remaining inside their stipulated budget. The proposal was to deliver good value per treatment. This would be achieved by having a high-performance team, in which members could deliver big volume with great quality (low complication rates). As the budget was limited, having fewer members allowed greater individual payment (with an above-market capital per hour worked). Additionally, achieving results of excellence ultimately reduced the value of any given treatment, indirectly saving money.

Let us consider the most common procedure performed, the cholecystectomy. This is considered a simple and low-risk surgery; however, its complications may cost up to 10,000 USD (300,000 USD during the patient's life $)^{8}$. Comparing the results of our 4,121 cases with two huge series $\left(n: 39,238^{\circ} \mathrm{e}\right.$ $9,542^{10}$ ), our major complications index was inferior $(0.07 \%$ vs $1 \%)$, as was iatrogenic biliary tree lesions (0.07\% vs $0.17-0.63 \%)$ and re-dos (0.02\% vs $0.9 \%)$. Safety was always a concern and peritoneum was created in open fashion, reducing the risk for iatrogenic bowel injury (incidence of $0.04 \%$, compared to $0.06 \%{ }^{9}$ ).

Indeed, the results were better than anticipated. The hospital infection rate was very low. This may be partially credited to the safety measures established. Patients were educated, took a chlorhexidine bath before surgery, trichotomy was performed in the operating room, prophylactic antibiotics were used, among other measures. Incisional hernias had the greatest infection index, but still very low compared to the literature (3.3\% vs up to $16 \%)^{11}$. For instance, those with body mass index $>30$ were lectured and underwent endocrine and nutritional support, losing weight before surgery.

It is a strong belief that the main action to achieve good results was the team's selection. They were required to have technical and moral excellence. Experience, knowledge, no previous ethical faults, capacity to work in a group, resilient personality, and traits of perseverance and self-control were must-have virtues. The interviewing process and curriculum analysis helped to identify the correct professionals, and the solid project with good payment attracted them. To keep these professionals, a sense of unity was created. They were part of a uniform team, with shared mindset and objectives; all were important, empowered, had their opinions valued, and could share responsibility.

Before starting, few meetings were arranged, so people got acquainted, questions were answered, problems and possible solutions anticipated, and the objectives were clearly established. During the years, this was nurtured. To help build a strong uniform team, periodic meetings were promoted.

Another important issue was the progressive increase in workload. This allowed the team to get familiar with the system, the hospital and other teams, and to identify and solve issues that restricted productivity. With time, everybody's (surgical team, hospital staff) capacity to tolerate higher volume with the same, or even lower index of flaws, increased.

Since the beginning, complex procedures were centralized in determined surgeons, while others could be scheduled on any given day. Laparoscopic gastroesophageal reflux for instance had unsatisfactory results initially. After identifying this, the procedure was restricted, those willing to learn were invited to observe first, then perform under supervision, and only then allowed to operate without an observer. Superior results were then achieved.

As exemplified above, periodic checks were necessary to verify results and eventually provide corrections. Besides the insurer quality metrics (i.e.: median length of hospital stay, surgery cancellation, ICU stay, treatment value, patient complaints and compliments), a prospective database was created and fed daily. Both parts shared and discussed these indexes regularly, collaborating with ideas and measures to keep improving value.

In a world of increasing healthcare costs, focus should be given to value. In general surgery, a 
high-performance team is a cost-effective option. Although literature concerning building and managing such medical teams is scarce, there are probably countless ideas and methods worth considering. The ones presented here are based on the achieved results and intend to broaden thinking and help leaders make better decisions.

Author's Contribution

All authors have contributed equally to this work

\section{RESUMO}

INTRODUÇÃO: No futuro as cirurgias serão centralizadas em hospitais que tenham melhor valor (resultados excelentes com custo reduzido). Equipes de alta performance serão necessárias, entretanto a literatura acerca das habilidades específicas para montar e gerir essas equipes é muito pobre.

OBJETIVOS: Compartilhar as competências e habilidades estabelecidas para construir e liderar uma equipe de cirurgia geral de alto desempenho.

MÉTODOS: Em novembro de 2012, a equipe de cirurgia geral iniciou suas atividades em um hospital terciário na cidade de São Paulo (SP, Brasil). O modelo consistia em produzir alto volume com um time pequeno. Cirurgiões experientes, motivados e com excelência técnica e moral foram selecionados. Um senso de unidade foi criado e objetivos coletivos estabelecidos e compartilhados. O pagamento estava acima da média do mercado.

RESULTADOS: Em 6 anos e 4 meses, 11.006 procedimentos cirúrgicos foram realizados (8.597 eletivos e 2.409 de urgência/emergência). A colecistectomia foi o procedimento mais comum ( $\mathrm{n}: 4.101$, sendo 3.676 eletivas), seguida da hernioplastia inguinal (n: 1.827) e da apendicectomia (n: 925). Um total de 449 cirurgias oncológicas eletivas foram realizadas. A infecção de sítio cirúrgico em procedimentos limpos foi de 0,12\% (2,4\% para cirurgias de urgência e 0,2\% nas eletivas). Ocorreram 22 óbitos cirúrgicos (0,66\% na urgência e 0,07\% nas eletivas), 5 dos 6 óbitos eletivos ocorreram em pacientes oncológicos.

CONCLUSÃo: Uma equipe competente, inserida em um modelo que favorece o desempenho e valoriza o indivíduo é capaz de entregar grande volume com resultados excepcionais.

PALAVRAS-CHAVE: Equipe de Assistência ao Paciente. Cirurgia geral. Gestão em Saúde. Avaliação de Resultados em Cuidados de Saúde.

\section{REFERENCES}

1. NEIM Catalyst. What is value-based healthcare? [cited 2020 Jul 01]. Available from: https://catalyst.nejm.org/what-is-value-based-healthcare/

2. National Institute for Health and Care Excellence. How NICE measures value for money in relation to public health interventions. [cited 2020 /ul 01]. Available from: https://www.nice.org.uk/Media/Default/guidance/ LGB10-Briefing-20150126.pdf

3. Porter ME. What is value in health care? N Engl | Med. 2010;363(26):2477-81.

4. Lam SM. How to create high-performing teams. Facial Plast Surg. 2010;26(1):16-20.

5. Dias AR, Szor DJ, Ferreira CBA, Navarro CL. Uncommon cause of liver abscess. Clin Case Rep. 2018;6(8):1649-50.

6. Szor DJ, Dias AR. Gastric trichobezoar. Clin Case Rep. 2017;5(11):1907.
7. Szor D, Dias AR. Laparoscopic resection of a gastric trichobezoar. Videoscopy. 2018;28(4). doi: 10.1089/vor.2017.0494.

8. Woods MS. Estimated costs of biliary tract complications in laparoscopic cholecystectomy based upon Medicare cost/charge ratios. A case-control study. Surg Endosc. 1996;10(10):1004-7.

9. Huang $X$, Feng $Y$, Huang Z. Complications of laparoscopic cholecystectomy in China: an analysis of 39,238 cases. Chin Med I (Engl). 1997;110(9):704-6.

10. Duca S, Bãlã O, Al-Hajjar N, Lancu C, Puia IC, Munteanu D, et al. Laparoscopic cholecystectomy: incidents and complications. A retrospective analysis of 9542 consecutive laparoscopic operations. HPB (Oxford). 2003,5(3):152-8.

11. Juvany M, Hoyuela C, Trias M, Carvajal F, Ardid J, Martrat A. Impact of surgical site infections on elective incisional hernia surgery: a prospective study. Surg Infect (Larchmt). 2018. doi: 10.1089/sur.2017.233. 